\title{
Variation of major elements and heavy metals occurrence in hybrid aspen (Populus tremuloides Michx. $\times$ P. tremula L.) tree rings in marginal land
}

\author{
Arta Bardule ${ }^{(1-2)}$, \\ Maris Bertins ${ }^{(2)}$, \\ Lauma Busa ${ }^{(2)}$, \\ Dagnija Lazdina $^{(1)}$, \\ Arturs Viksna ${ }^{(2)}$, \\ Michaela Tvrdonova ${ }^{(3-4)}$, \\ Viktor Kanicky ${ }^{(3-4)}$, \\ Tomas Vaculovic ${ }^{(3-4)}$
}

Fast growing tree species such as Populus spp. in short rotation woody crop (SRWC) systems could be an environmentally friendly and cost-effective approach to ensure sustainable biomass production and mitigate the negative impacts on the environment caused by more intensive management aimed to promote additional biomass increment. Knowledge on variation of major biologically important elements' and toxic heavy metals' occurrence in fertilised hybrid aspen tree rings in marginal land may have important and relevant implications for the management practice and evaluation of element fluxes in SRWC ecosystems. Laser ablation inductively coupled plasma mass spectrometry (LA-ICP-MS) was used to determine the relative amount of major elements $(\mathrm{K}, \mathrm{Ca}, \mathrm{Mg}, \mathrm{P})$ and heavy metals $(\mathrm{Cd}, \mathrm{Hg}, \mathrm{Pb})$ in stem wood plane on straight line trajectory starting from pith to bark with measurement step $0.1 \mathrm{~mm}$. While inductively coupled plasma mass spectrometry (ICP-MS) was used to determine average content of the mentioned elements in mechanically separated tree rings to quantify data obtained using LA-ICP-MS method and expressed in relative units. Stem disc samples were collected from six year old hybrid aspen trees growing in marginal agricultural land in the central part of Latvia (hemi-boreal climate conditions) that were initially fertilised with biogas production residues, sewage sludge, and wood ash. We concluded that the content of analysed major elements and heavy metals in the hybrid aspen tree rings varied considerably not only within the analysed stem plane (across tree rings) of one sample tree, but also within one annual ring with significant differences between the content of major elements in earlywood and latewood. Nevertheless, the results of the content of major elements and heavy metals in hybrid aspen tree rings highlighted the significant impact of the initially used fertiliser (especially wood ash) on the average content of elements. Hybrid aspens can be considered bioindicators of both the management activities and general growing conditions even if soil $\mathrm{pH}$ is close to neutrality, suggesting a limited mobility of the heavy metals.

Keywords: Dendroanalyses, Hybrid Aspen, Tree Rings, Major Elements, Heavy Metals, LA-ICP-MS

mass; they also accumulate and store biologically important elements and contaminants from the surroundings, thus acting as passive samplers (Burken et al. 2011).
Plants have evolved to be extremely proficient in mass transfer with their surroundings and to survive as earth's dominant bio-
Fast growing tree species such as Populus spp. in short rotation woody crop (SRWC) systems may efficiently meet societal needs ranging from renewable energy sources (used as alternative production systems that reduce pressure on native forests) to environmental mitigation by phytoremediation, which is the use of plants for the in situ treatment of contaminated soils, sediments, and water (Schnoor 1997, Rockwood et al. 2004, Mala et al. 2007). In addition, Populus spp. are characterised by high genomic plasticity, an important aspect for adaptation to the predicted extremes of meteorological conditions, e.g., summer drought (Viger et al. 2016).

In cases of non-hyperaccumulating contaminants (i.e., relatively low contaminant concentrations), species such as Populus spp. may phytoremediate while simultaneously providing revenue from fuelwood and other timber products (Rockwood et 
al. 2004). Populus spp. trees are optimal plants for the absorption, accumulation, storage, and degradation of environmental pollutants, such as heavy metals, pesticide residues, fertilisers and nitrates, petroleum hydrocarbons, landfill leachates, salts, explosives, and other waste products (Mala et al. 2007, Zalesny 2007, Valujeva et al. 2016). Use of fast-growing trees with a good phytoremediation capacity in SRWC systems is an emerging holistic approach for sustainable energy, agricultural and agroforestry development, utilisation of marginal lands (Ghezehei et al. 2015, Blanco-Canqui 2016), and global environmental mitigation (Rockwood et al. 2004, Ghezehei et al. 2015).

Trees from temperate and boreal regions usually form visible annual growth rings that can be dated accurately. Hence, it is possible to collect wood samples of different ages to analyse the elemental composition of the tree rings (Nabais et al. 1999, Sensula et al. 2017). This method is known as dendrochemistry, i.e., the chronological analysis of elements in the annual growth rings of wood (Nabais et al. 1999, Scharnweber et al. 2016, Sensula et al. 2017). An important assumption in dendrochemistry is that the elemental concentrations in a given growth ring are the result of environmental conditions at the time of wood formation (Berger et al. 2004, Vaganov et al. 2013, Maillard et al. 2016). Dendrochemistry is still an evolving scientific field (Scharnweber et al. 2016), whose applications include the biomonitoring of environmental pollution (Cocozza et al. 2016), reconstruction of longer-term changes in environmental conditions, or the detection and dating of volcanic eruptions, etc. (Komárek et al. 2008). It should be mentioned that due to the complex nature of uptake, transportation, incorporation, and remobilisation of various elements and the mixed signal of structural (wood) and non-structural (xylem sap) compounds, any conclusions on environmental signals in dendrochemical research have to be interpreted with caution (Scharnweber et al. 2016).

Many techniques have been used to analyse the matrix and trace elements including the toxic heavy metal content of tree

Tab. 1 - Major element (K, Ca, Mg, P) total concentration in soil after the application of fertilisers in the experimental plot.

\begin{tabular}{|c|c|c|c|c|c|}
\hline \multirow[b]{2}{*}{ Soil depth } & \multirow{2}{*}{$\begin{array}{l}\text { Element, } \\
\text { unit }\end{array}$} & \multicolumn{4}{|c|}{ Fertilizer } \\
\hline & & control & digestate & $\begin{array}{l}\text { sewage } \\
\text { sludge }\end{array}$ & wood ash \\
\hline \multirow[t]{4}{*}{$0-20 \mathrm{~cm}$} & $\mathrm{~K}, \mathrm{~g} \mathrm{~kg}^{-1}$ & $2.05 \pm 0.27$ & $1.86 \pm 0.26$ & $1.66 \pm 0.24$ & $2.10 \pm 0.18$ \\
\hline & $\mathrm{Ca}, \mathrm{g} \mathrm{kg}^{-1}$ & $2.71 \pm 0.81$ & $2.30 \pm 8.10$ & $1.84 \pm 2.20$ & $2.41 \pm 8.94$ \\
\hline & $M g, \mathrm{~g} \mathrm{~kg}^{-1}$ & $2.30 \pm 0.23$ & $2.08 \pm 1.04$ & $1.89 \pm 0.28$ & $2.41 \pm 0.18$ \\
\hline & $P, \mathrm{~g} \mathrm{~kg}^{-1}$ & $0.81 \pm 0.24$ & $0.65 \pm 0.12$ & $0.62 \pm 0.08$ & $0.66 \pm 0.18$ \\
\hline \multirow[t]{4}{*}{$20-80 \mathrm{~cm}$} & $\mathrm{~K}, \mathrm{~g} \mathrm{~kg}^{-1}$ & $2.96 \pm 0.44$ & $2.38 \pm 0.29$ & $2.68 \pm 0.34$ & $2.83 \pm 0.28$ \\
\hline & $\mathrm{Ca}, \mathrm{g} \mathrm{kg}^{-1}$ & $2.69 \pm 0.55$ & $8.22 \pm 4.60$ & $2.54 \pm 1.05$ & $6.37 \pm 4.21$ \\
\hline & $M g, \mathrm{~g} \mathrm{~kg}^{-1}$ & $3.04 \pm 0.35$ & $4.18 \pm 1.26$ & $3.18 \pm 0.43$ & $3.63 \pm 0.59$ \\
\hline & $\mathrm{P}, \mathrm{g} \mathrm{kg}^{-1}$ & $0.71 \pm 0.20$ & $0.46 \pm 0.06$ & $0.33 \pm 0.03$ & $0.44 \pm 0.07$ \\
\hline
\end{tabular}

six-year-old hybrid aspen (Populus tremuloides Michx. $\times$ P. tremula $L$.) trees growing on an experimental plot in marginal agricultural land in the central part of Latvia (56.6919 N, 25.1370 E, according to the LKS92 coordinate system, Transverse Mercator projection). Biophysical criteria underpinning the marginality of the study site were excess soil moisture, unfavourable texture, and stoniness (Confalonieri et al. 2014). The experimental plot was established in the spring of 2011. Hybrid aspen seedlings (clone No. 4), produced in a nursery of Joint Stock Company "Latvia's State Forests", Latvia, were planted with a $2.0 \times 2.0$ $m$ average distance between the trees. The experimental plot of the hybrid aspens was part of a large-scale multifunctional plantation of short rotation energy crops and deciduous trees with a total area of 16 ha. The type of soil was classified as Luvic Stagnic Phaeozem (Hypoalbic) or Mollic Stagnosol (Ruptic, Calcaric, Endosiltic) according to the Food and Agriculture Organization of the United Nations classification (2006) with the dominant loam (at 0-20 cm depth) and sandy loam (at $0-20 \mathrm{~cm}$ and $20-80 \mathrm{~cm}$ depth) soil texture.

Four replications of four different fertilisation subplots were established: control (no fertilisation), sewage sludge, wood ash, and biogas production residues (digestate). The size of each subplot was $30 \times 24$ $\mathrm{m}$ and they were established in the spring of 2011. Class I (according to the regulations of the Cabinet of Ministers of the Republic of Latvia No. 362) sewage sludge (dose $10 t_{D M} h^{-1}$ ) from "Aizkrauklesūdens" (Aizkraukle Water) and stabilised wood ash from the boiler house in Sigulda (dose $6 t_{D M}$ $\mathrm{ha}^{-1}$ ) were spread mechanically before planting the hybrid aspens. Digestate (as a point source fertiliser, dose $30 \mathrm{t} \mathrm{ha}^{-1}$ ) from the methane reactor in the Vecauce district (Latvia) was applied immediately after planting the hybrid aspen seedlings. Immediately after the application of fertilisers, soil chemical analyses were done. Major elements and heavy metals concentration in soil samples were determined using extraction with a mixture of concentrated $\mathrm{HNO}_{3}$ and $\mathrm{HClO}_{4}$ and determination using an inductively coupled plasma optical emission spectrometry (ICP-OES).

According to the results of soil chemical analyses, no statistically significant differences $(p>0.05)$ between major element $(\mathrm{K}, \mathrm{Ca}, \mathrm{Mg}, \mathrm{P})$ and toxic heavy metal $(\mathrm{Cd}$, $\mathrm{Hg}, \mathrm{Pb}$ ) content in fertilised soils and control plots were detected, although it is well known that previously-used fertilisers contain both a certain amount of nutrients and heavy metals (Tab. 1, Tab. 2). Furthermore, the heavy metal target values and precautionary limits were not exceeded in the fertilised soils as per legislative regulations for soil and ground quality (Regulations of the Cabinet of Ministers of the Republic of Latvia No. 804). 
Tree disc sampling and preparation

Three sample trees from four different fertilisation subplots (digestate, sewage sludge, wood ash, and control or no fertilisation) were selected (Tab. 3). Stem discs were sawn at a $0.20 \mathrm{~m}$ height with the aim of representing all tree rings (six in total) in the samples, while the thickness of the tree discs was approximately $2 \mathrm{~cm}$. Discs were air dried and abraded with trace metal free sandpaper. Discs were split into pieces with a maximum diameter $4.0 \mathrm{~cm}$.

\section{LA-ICP-MS analyses}

Samples of tree rings were analysed by LA-ICP-MS. The instrumentation consisted of a laser ablation system UP213 ${ }^{\circledR}$ (New Wave Research Inc., Fremont, CA, USA) that generated aerosols of the sample from the sample surface, and an ICP-MS Agilent $7500 \mathrm{Ce}^{\circledast}$ (Agilent Technologies Ltd, Japan) was used to detect the isotopes. Ablation parameters were optimised with respect to achieving the best $\mathrm{S} / \mathrm{N}$ (signalto-noise) ratio and lateral resolution using glass reference material National Institute of Standards and Technology (NIST) 610. NIST 610 (SRM 610 - Trace Elements in Glass) is the standard reference material (SRM) produced and certified to facilitate the development of chemical methods of analysis for trace elements. Optimised laser ablation parameters were applied for the analysis of all measured samples: laser spot size $100 \mu \mathrm{m}$; scan speed $70 \mu \mathrm{m} \mathrm{s}^{-1}$; laser beam fluence $2.5 \mathrm{~J} \mathrm{~cm}^{-2}$; repetition rate $10 \mathrm{~Hz}$; carrier gas flow $1.0 \mathrm{~L}$ He $\mathrm{min}^{-1}$.

The sample was placed into a SuperCell ${ }^{\circledast}$ (New Wave Research) with a volume of 33 $\mathrm{cm}^{3}$ and ablated using a commercial Qswitched $\mathrm{Nd}$ : YAG laser operated at a wavelength of $213 \mathrm{~nm}$. A line scan pattern was used for sample ablation. The sample was moved during laser ablation with a constant scan speed with a straight line trajectory. First, the ablation pattern went from the center of the tree ring (pith) to the edge of the sample (bark) across all annual tree rings. The second pattern was perpendicular to the first. An XY-stage was used to move the sample along a programmed trajectory and a charge coupled device (CCD) camera was used to monitor the ablation event. Ablated material was transported from the sample chamber using helium carrier gas $(1.0 \mathrm{~L} \mathrm{~min}-1)$ and mixed with argon ( $0.6 \mathrm{~L} \mathrm{~min}^{-1}$ ) prior to the torch. The following isotopes were determined in all samples: ${ }^{13} \mathrm{C}$ (for monitoring of ablation rate of tree samples), ${ }^{26} \mathrm{Mg},{ }^{39} \mathrm{~K}$, ${ }^{44} \mathrm{Ca}$, and ${ }^{31} \mathrm{P}$ (as the major elements), and ${ }^{111} \mathrm{Cd},{ }^{202} \mathrm{Hg}$, and ${ }^{208} \mathrm{~Pb}$ (as the heavy metals). Due to missing calibration standards of the wood sample, the NIST 610 was used for recalculation of the content of selected elements ( $\mathrm{Mg}, \mathrm{K}, \mathrm{Ca}, \mathrm{P}, \mathrm{Cd}, \mathrm{Hg}, \mathrm{Pb}$ ). When the matrix of NIST 610 is completely different from the wood sample, it means that amount of sample released by laser pulse is different for these various materials (called different ablation rate). Hence, we cannot
Tab. 2 - Toxic heavy metal ( $\mathrm{Cd}, \mathrm{Hg}, \mathrm{Pb})$ total content in soil after the application of fertilisers in the experimental plot. (LOD): limit of detection.

\begin{tabular}{|c|c|c|c|c|c|c|}
\hline \multirow{2}{*}{$\begin{array}{l}\text { Soil } \\
\text { depth }\end{array}$} & \multirow[b]{2}{*}{ Element } & \multirow{2}{*}{$\begin{array}{l}\text { Soil } \\
\text { texture }\end{array}$} & \multicolumn{4}{|c|}{ Fertilizer } \\
\hline & & & control & digestate & $\begin{array}{l}\text { sewage } \\
\text { sludge }\end{array}$ & wood ash \\
\hline \multirow{9}{*}{$\begin{array}{l}\text { Ė } \\
\text { Ò } \\
\text { ó }\end{array}$} & \multirow{3}{*}{$\begin{array}{l}\mathrm{Cd} \\
\mathrm{mg} \mathrm{kg}^{-1}\end{array}$} & loamy sand & $<L O D$ & $0.03 \pm 0.02$ & $0.07 \pm 0.01$ & $0.02 \pm 0.02$ \\
\hline & & loam & $0.12 \pm 0.04$ & 0.18 & $<L O D$ & $0.09 \pm 0.09$ \\
\hline & & average & $0.1 \pm 0.4$ & $0.07 \pm 0.04$ & $0.05 \pm 0.02$ & $0.06 \pm 0.04$ \\
\hline & \multirow{3}{*}{$\begin{array}{l}\mathrm{Hg}, \\
\mathrm{mg} \mathrm{kg}^{-1}\end{array}$} & loamy sand & 0.019 & $0.033 \pm 0.001$ & $0.037 \pm 0.002$ & $0.027 \pm 0.006$ \\
\hline & & loam & $0.05 \pm 0.01$ & 0.073 & 0.025 & $0.05 \pm 0.02$ \\
\hline & & average & $0.04 \pm 0.01$ & $0.04 \pm 0.01$ & $0.034 \pm 0.003$ & $0.04 \pm 0.01$ \\
\hline & \multirow{3}{*}{$\begin{array}{l}\mathrm{Pb} \\
\mathrm{mg} \mathrm{kg}^{-1}\end{array}$} & loamy sand & 6.7 & $8.1 \pm 0.5$ & $9.0 \pm 0.9$ & $9 \pm 1$ \\
\hline & & loam & $9.8 \pm 0.7$ & 11.1 & 8.7 & $10 \pm 2$ \\
\hline & & average & $9.0 \pm 0.9$ & $8.8 \pm 0.8$ & $9.0 \pm 0.6$ & $9.1 \pm 0.9$ \\
\hline \multirow{9}{*}{ 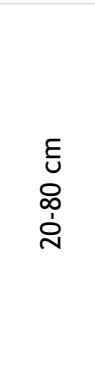 } & \multirow{3}{*}{$\begin{array}{l}\mathrm{Cd} \\
\mathrm{mg} \mathrm{kg}^{-1}\end{array}$} & loamy sand & $0.05 \pm 0.04$ & $0.012 \pm 0.008$ & $0.012 \pm 0.008$ & $<L O D$ \\
\hline & & loam & $0.12 \pm 0.07$ & $0.05 \pm 0.04$ & $<L O D$ & $0.03 \pm 0.03$ \\
\hline & & average & $0.07 \pm 004$ & $0.02 \pm 0.01$ & $0.009 \pm 0.006$ & $0.01 \pm 0.01$ \\
\hline & \multirow{3}{*}{$\begin{array}{l}\mathrm{Hg}, \\
\mathrm{mg} \mathrm{kg}^{-1}\end{array}$} & loamy sand & $0.03 \pm 0.01$ & $0.022 \pm 0.004$ & $0.021 \pm 0.002$ & $0.018 \pm 0.003$ \\
\hline & & loam & $0.05 \pm 0.02$ & $0.04 \pm 0.01$ & $0.019 \pm 0.002$ & $0.024 \pm 0.006$ \\
\hline & & average & $0.035 \pm 0.009$ & $0.028 \pm 0.005$ & $0.021 \pm 0.002$ & $0.021 \pm 0.004$ \\
\hline & \multirow{3}{*}{$\begin{array}{l}\mathrm{Pb} \\
\mathrm{mg} \mathrm{kg}^{-1}\end{array}$} & loamy sand & $7 \pm 1$ & $6.9 \pm 0.5$ & $6.6 \pm 0.5$ & $6.2 \pm 0.5$ \\
\hline & & loam & $10 \pm 1$ & $8.2 \pm 0.9$ & $6.3 \pm 0.3$ & $7.2 \pm 0.7$ \\
\hline & & average & $8.0 \pm 0.9$ & $7.3 \pm 0.5$ & $6.6 \pm 0.4$ & $6.8 \pm 0.5$ \\
\hline
\end{tabular}

use term content when the different ablation rate is not compensated. Therefore, the term "relative amount" was used in this paper. However, in our case the relative changes of the amount of elements were observed, meaning that compensation of different ablation rate of NIST 610 and wood samples was not necessary. The ablation rate of the tree samples was checked by ${ }^{13} \mathrm{C}$ measurements where it was found that its signal differed by less than $8 \%$ relative standard deviation (RSD) in individual samples, and 10-12\% RSD sample by sample. Based on this information, we concluded that the ablation rate between the individual samples did not vary significantly, and therefore we could compare the relative amount of elements to each other in each individual sample, and also sample by sample.

In addition, to evaluate the suitability of the LA-ICP-MS method for dendrochemistry and to demonstrate the benefits of the LA-ICP-MS method for mapping the relative amount of the mentioned major elements and heavy metals, the method was
Tab. 3 - Characterisation of six-year-old hybrid aspen sample trees selected for the chemical analyses in the experimental plot (at the stem discs sampling time). (DBH): Diameter at breast height $(1.3 \mathrm{~m})$.

\begin{tabular}{|c|c|c|c|c|c|}
\hline \multirow[t]{2}{*}{ Fertilizer } & \multirow{2}{*}{$\begin{array}{l}\text { Sample tree } \\
\text { (ID) }\end{array}$} & \multirow{2}{*}{$\begin{array}{l}\text { Tree height } \\
\text { (m) }\end{array}$} & \multicolumn{2}{|c|}{ Naturally wet biomass (kg) } & \multirow{2}{*}{$\begin{array}{l}\text { DBH } \\
(\mathrm{mm})\end{array}$} \\
\hline & & & Stem & Branch & \\
\hline \multirow[t]{4}{*}{ Control } & A 1 & 8.25 & 12.10 & 2.95 & 63 \\
\hline & A 5 & 9.14 & 17.10 & 4.10 & 71 \\
\hline & A 9 & 9.82 & 17.52 & 4.88 & 75 \\
\hline & average & $9.07 \pm 0.45$ & $15.57 \pm 1.74$ & $3.98 \pm 0.56$ & $70 \pm 4$ \\
\hline \multirow{4}{*}{$\begin{array}{l}\text { Sewage } \\
\text { sludge }\end{array}$} & A 2 & 9.16 & 16.26 & 3.88 & 76 \\
\hline & A 8 & 9.81 & 23.10 & 7.42 & 89 \\
\hline & A 11 & 8.91 & 20.22 & 7.86 & 86 \\
\hline & average & $9.29 \pm 0.27$ & $19.86 \pm 1.98$ & $6.39 \pm 1.26$ & $84 \pm 4$ \\
\hline \multirow[t]{4}{*}{ Digestate } & A 3 & 9.70 & 20.94 & 8.52 & 83 \\
\hline & A 6 & 11.20 & 32.58 & 11.66 & 95 \\
\hline & A 10 & 10.83 & 29.84 & 8.50 & 94 \\
\hline & average & $10.58 \pm 0.45$ & $27.79 \pm 3.51$ & $9.56 \pm 1.05$ & $91 \pm 4$ \\
\hline \multirow[t]{4}{*}{ Wood ash } & A 4 & 7.25 & 12.22 & 5.18 & 65 \\
\hline & A 7 & 8.93 & 17.82 & 8.34 & 81 \\
\hline & A 12 & 6.53 & 5.82 & 1.50 & 52 \\
\hline & average & $7.57 \pm 0.71$ & $11.95 \pm 3.47$ & $5.01 \pm 1.98$ & $66 \pm 8$ \\
\hline
\end{tabular}


Tab. 4 - Parameters of the relationship (linear regression) between data obtained using ICP-MS method (average content of elements in tree rings) and data obtained using LA-ICP-MS method (average relative amount of elements in tree rings). $\left(^{*}\right)$ : Equation describes linear regression between content of elements $\left(\mathrm{mg} \mathrm{kg}^{-1}\right)$ in tree rings (ICP-MS method) and average relative amount of elements (relative units) in the same tree rings (LA-ICP-MS method); $(y)$; content of element; $(x)$ : relative amount of element. $(* *)$ : Hg content in tree rings determined using ICP-MS method is below detection limit $\left(<0.06 \mathrm{mg} \mathrm{kg}^{-1}\right)$.

\begin{tabular}{lccl}
\hline Element & $\begin{array}{c}\text { Pearson's correlation } \\
\text { coefficient }(\mathbf{r})\end{array}$ & $\begin{array}{c}\text { Determination } \\
\text { coefficient }\left(\mathbf{R}^{2}\right)\end{array}$ & Equation $\left.{ }^{*}\right)$ \\
\hline $\mathrm{Mg}$ & 0.90 & 0.81 & $\mathrm{y}=0.08 \cdot x+151.54$ \\
$\mathrm{~K}$ & 0.92 & 0.85 & $\mathrm{y}=0.29 \cdot x+382.03$ \\
$\mathrm{Ca}$ & 0.83 & 0.68 & $\mathrm{y}=0.0044 \cdot x+206.48$ \\
$\mathrm{P}$ & 0.94 & 0.89 & $\mathrm{y}=0.44 \cdot x+67.72$ \\
$\mathrm{Cd}$ & 0.81 & 0.65 & $\mathrm{y}=0.042 \cdot x+0.087$ \\
$\mathrm{~Pb}$ & 0.89 & 0.79 & $\mathrm{y}=0.026 \cdot x-0.020$ \\
\hline $\mathrm{Hg}{ }^{(*)}$ & - & - & - \\
\hline
\end{tabular}

performed on one sample (the first three tree rings of sample tree A4 were mapped).

Sample preparation for ICP-MS analyses

Sample discs were sawn to a thickness of approximately $0.5 \mathrm{~cm}$. For the analysis with LA-ICP-MS, a part of sample near the previously burned line was taken from different

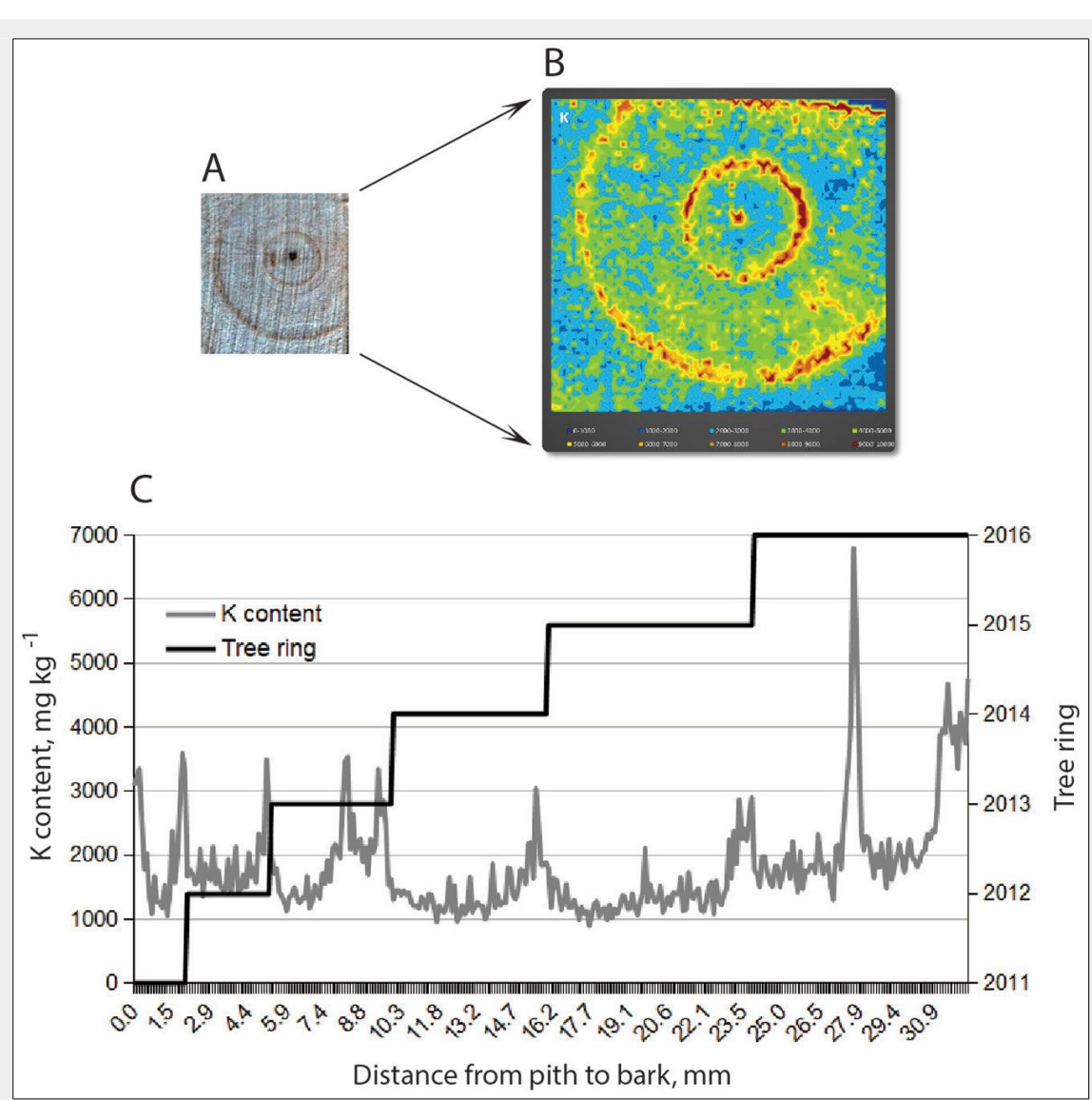

Fig. 1 - Example of mapping of $K$ relative amount $(B)$ in the first three hybrid aspen tree rings (2011-2013) of the sample tree $\mathrm{A} 4,(\mathrm{~A})$ using LA-ICP-MS method and variation of $K$ content in hybrid aspen tree rings (2011-2016) depending on the distance from pith to bark calculated using quantified data obtained using the LA-ICP-MS method (C). stone, Shelton, CT, USA). Digestion temperature was raised to $150^{\circ} \mathrm{C}$ in $15 \mathrm{~min}$, and then held for another $30 \mathrm{~min}$. Digested samples were transferred to $25 \mathrm{~mL}$ volumetric flasks and diluted with deionised water until mark.

\section{ICP-MS analyses}

Determination of elements was done by inductively coupled plasma mass spectrometry (ICP-MS). Analysis was performed using Agilent Technologies 8900 ICP-QQQ mass spectrometer. The instrumental parameters were set as follows: RF power $1550 \mathrm{~W}$, sampling depth $8 \mathrm{~mm}$, nebulizer gas flow $1.0 \mathrm{~L} \mathrm{~min}^{-1}$, auxiliary gas flow $0.9 \mathrm{~L}$ $\mathrm{min}^{-1}$. Helium was used as a collision cell gas with a flow rate of $5.0 \mathrm{~mL} \mathrm{~min}^{-1}$. For the quantification of all elements, a five-point calibration graph method with blank correction was applied. Element standard solutions in the concentration range from 0.5 to $100.0 \mu \mathrm{g} \mathrm{L}^{-1}$ were prepared from Trace$\mathrm{CERT}^{\circledR}$ inorganic standard stock solution for ICP with concentration of elements of 100 $\mathrm{mg} \mathrm{L}^{-1}$ (Sigma-Aldrich, St. Louis, MO, USA). In total, 13 samples representing separate tree rings from three sample trees, were analysed.

\section{Quantification of data obtained by laser ablation ICP-MS}

Data obtained by the ICP-MS method (average content of elements in each separate tree ring; in total, 13 tree rings were analysed) was used to determine data obtained by LA-ICP-MS (average values of relative amount of elements in the same tree rings were calculated). Parameters characterising the relationship between data obtained using the ICP-MS method (average content of elements in tree rings) and data obtained using LA-ICP-MS method (average relative amount of elements in tree rings) are summarised in Tab. 4.

\section{Statistical analysis}

The data of the content or relative amount of major elements and toxic heavy metals in tree rings of hybrid aspen were divided into four groups according to differences in fertiliser source. Data processing was performed in OpenOffice ${ }^{\circledast}$ 4.1.1 Calc and R (R Core Team 2017). The correspondence of the dataset to the nominal distribution was verified using graphical analysis (function qqPlot of the package "car") in the program $R$, which plots empirical quantiles of a variable, or of studentised residuals from a linear model, against theoretical quantiles of a comparison distribution. Pearson's correlation coefficients were used to estimate the correlations between the average content of heavy metals and major elements in the annual tree rings at an individual tree level. Differences of statistics in the average content or relative amount of elements in hybrid aspen tree rings between treatments were analysed by pairwise comparisons using $t$-tests with pooled standard deviation. 


\section{Results and discussion}

Dendrochemistry has the potential to detect and reconstruct environmental changes that influence soil chemistry over the life of the tree (Smith \& Shortle 1996, Watmough 1997, DeWalle et al. 2002, Cui et al. 2012). It is generally accepted that the mineral content of tree stem wood partly depends on the chemical composition of xylem sap (Levy et al. 1996). The elemental content of each tree ring may reflect to a certain extent the properties characterising the soil and availability of elements during the year when the ring was formed (Yanosky \& Carmichael 1993, Levy et al. 1996). This is the reason why tree ring analysis has been used for several years to investigate historical changes that have occurred in the soil chemistry (Levy et al. 1996).

\section{Variation in the content of major elements}

Chemical elements associated with the ionic composition of the cytoplasm of cells are crucial components of higher plants. They enable various processes throughout the lifetime of plants associated with cellular energy, operation of a large number of enzymes, etc. (Taiz \& Zeiger 2010, Vaganov et al. 2013). Published data on the radial distribution of elements in stem wood are relatively scarce and do not always agree (Saarela 2009), highlighting knowledge gaps in dendrochemistry.

The results of our study showed a large variability in the content of major biologically important elements, not only between hybrid aspen sample trees, but also in the plane of stem wood of hybrid aspen trees (across tree rings). Furthermore significant differences were found between the content of major elements in earlywood and latewood in annual tree rings; the content in latewood was generally higher showing a pronounced ring structure (Fig. 1). The most abundant element in hybrid aspen stem wood samples was K, which is an important component of the cytoplasm. The average major element content in wood samples decreased: $[\mathrm{K}]$ > $[\mathrm{Mg}]>[\mathrm{Ca}]>[\mathrm{P}]$. The average $\mathrm{K}$ content in a tree ring ranged from $776 \mathrm{mg} \mathrm{kg}^{-1}$ (relative amount 138) in the plot initially fertilised with sewage sludge (sample tree A8, tree ring formed in 2013) to $5810 \mathrm{mg} \mathrm{kg}^{-1}$ (relative amount 19,000) in the plot initially fertilised with digestate (sample tree A10, tree ring formed in 2016). The average $\mathrm{Mg}$ content in a tree ring ranged from $157 \mathrm{mg}$ $\mathrm{kg}^{-1}$ (relative amount 62.0) in the plot initially fertilised with digestate (sample tree A10, tree ring formed in 2015) to 5,080 mg $\mathrm{kg}^{-1}$ (relative amount 61,600) in the plot initially fertilised with wood ash (sample tree A12, tree ring formed in 2011). The average Ca content in a tree ring ranged from 236 $\mathrm{mg} \mathrm{kg}^{-1}$ (relative amount 677) in the plot initially fertilised with wood ash (sample tree A4, tree ring formed in 2012) to $1450 \mathrm{mg}$ $\mathrm{kg}^{-1}$ (relative amount 282,000) in the plot initially fertilised with wood ash (sample

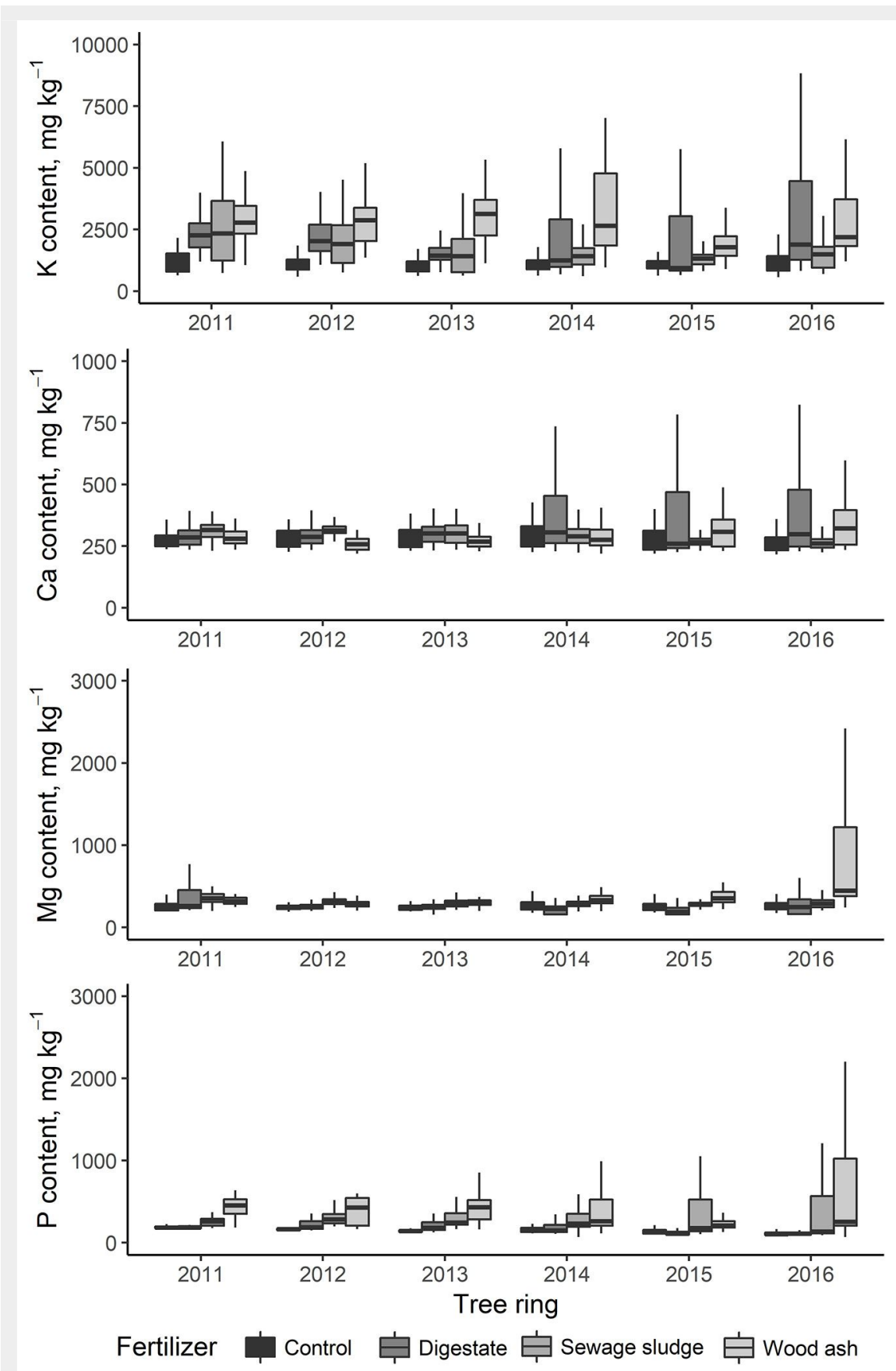

Fig. 2 - Content of major elements in hybrid aspen tree rings (2011-2016). In the boxplots, the median is shown by the bold line, the box corresponds to the lower and upper quartiles, whiskers show the minimal and maximal values (within 150\% of the interquartile range from the median).

tree A12, tree ring formed in 2012), but the average tree ring $\mathrm{P}$ content was from 99.7 $\mathrm{mg} \mathrm{kg}^{-1}$ (relative amount 73.0) in the control plot (sample tree $\mathrm{A}_{5}$, tree ring formed in 2016) to $2,430 \mathrm{mg} \mathrm{kg}^{-1}$ (relative amount 5,370 ) in the plot initially fertilised with wood ash (sample tree A12, tree ring formed in 2011).

$\mathrm{N}, \mathrm{P}$, and $\mathrm{K}$ are the main macronutrients essential for tree metabolism and various physiological processes related to growth (Fromm 2010, Vaganov et al. 2013). Relationships between the average content of major biologically-important elements in stem wood of hybrid aspen trees and soil properties (Tab. 1) or parameters which characterise sample trees (Tab. 3) were evaluated and significant correlations were not detected.

Variation of average content of major elements in hybrid aspen tree rings (20112016) by initially used fertilisers is summarised in Fig. 2. Comparing the average major element content in the hybrid aspen tree rings in control plots and plots where different fertilisers were initially used, statistically significant impact of fertilisation was detected. The highest average content of major elements was detected in plots where wood ash fertiliser was applied and 
the lowest was found in the control plots. Increased major element ( $\mathrm{Ca}, \mathrm{Mg}, \mathrm{P}$ ) content in stem wood plane was found for sample tree A12 (plot where wood ash fertiliser was initially applied). Also soil analysis showed elevated $\mathrm{Ca}$ and $\mathrm{Mg}$ total content in the soil in the relevant plot (plot where sample tree A12 was grown), when compared to all other plots including plots initially fertilised with wood ash, although in general correlation between content amount of major elements in stem wood of hybrid aspen trees and soil properties was not detected. Furthermore, biomass increment parameters (Tab. 3) of sample tree 12 were the lowest compared to all other analysed trees.

\section{Variation in heavy metal content}

Understanding the process governing the migration and plant availability of trace metals in soils is essential for predicting the environmental impact of spreading metalcontaining wastes such as wood ash and sewage sludge on agricultural land (Sherene 2010). The results demonstrated a large variability in the content of $\mathrm{Pb}$ and $\mathrm{Cd}$ within tree stems: $\mathrm{Pb}$ content ranged up to $18.5 \mathrm{mg} \mathrm{kg}^{-1}$ (relative amount 720) and $\mathrm{Cd}$ content was up to $33.9 \mathrm{mg} \mathrm{kg}^{-1}$ (relative amount 804); within the annual tree ring, there were a large number of peaks or outliers in the datasets (Fig. 3). Furthermore, there were no significant trends in the tree rings representing changes in heavy metal uptake during tree ring formation. In con- trast to the macroelements ( $\mathrm{Ca}, \mathrm{Mg}, \mathrm{K}$, etc.) that mostly showed significant differences between elemental contents in earlywood and latewood (Saarela 2009, Silkin \& Ekimova 2012), no significant differences were found between the content of heavy metals in earlywood and latewood in annual tree rings. Additionally, the results of our study showed that the average heavy metal content in tree rings decreased in the following order: $[\mathrm{Pb}]>[\mathrm{Cd}]>[\mathrm{Hg}]$, similar to the soil in the experimental plot (Tab. 2).

The average $\mathrm{Pb}$ content in tree rings ranged from $0.07 \mathrm{mg} \mathrm{kg}^{-1}$ (relative amount 3.5) in the plot initially fertilised with digestate (sample tree $\mathrm{A}_{3}$, tree ring formed in 2016) to $2.7 \mathrm{mg} \mathrm{kg}^{-1}$ (relative amount 105) in the plot initially fertilised with wood ash (sample tree A12, tree ring formed in 2016), but the average tree ring $\mathrm{Cd}$ content ranged from $0.09 \mathrm{mg} \mathrm{kg}^{-1}$ (relative amount 0.07 ) in the plot initially fertilised with digestate (sample tree A10, tree ring formed in 2014) to $6.2 \mathrm{mg} \mathrm{kg}^{-1}$ (relative amount 146) in the plot initially fertilised with wood ash (sample tree A12, tree ring formed in 2016). Although the $\mathrm{pH}$ of the soil in the plots was near neutral, indicating a limited mobility of the heavy metals (Sherene 2010), the average $\mathrm{Pb}$ content in the hybrid aspen tree rings was significantly different $(p<$ 0.05 ) between the control and fertilised plots; higher $\mathrm{Pb}$ content in tree rings of hybrid aspen were found in fertilised plots, e.g., $1.2 \mathrm{mg} \mathrm{kg}^{-1}$ (relative amount 50 ) in
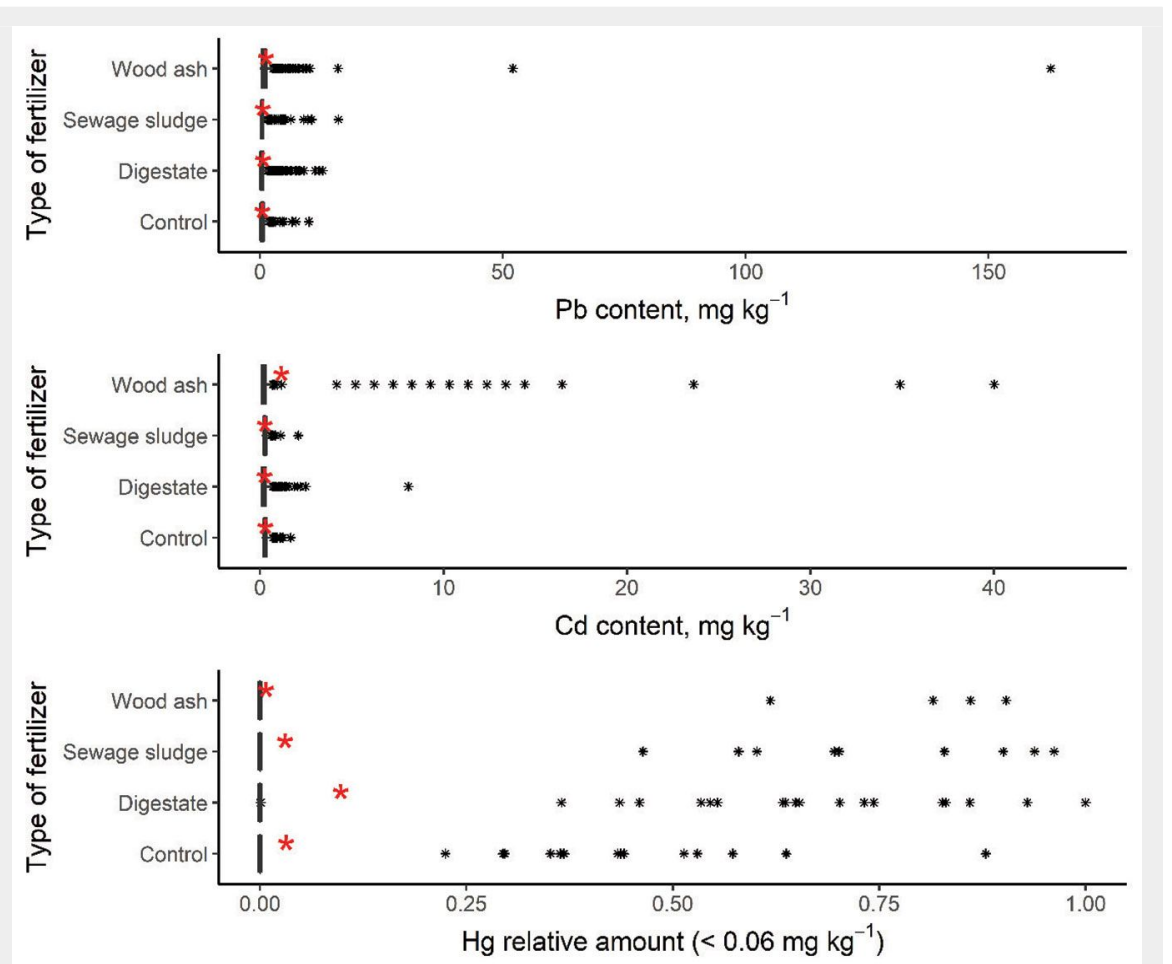

Fig. 3 - Variation of $\mathrm{Pb}, \mathrm{Cd}$, and $\mathrm{Hg}$ content in hybrid aspen tree rings (2011-2016). In the boxplots, the median is shown by the bold line, the mean is shown by the red star, the box corresponds to the lower and upper quartiles, whiskers show the minimal and maximal values (within $150 \%$ of the interquartile range from the median) and black stars represent outliers of the datasets. plots with wood ash fertiliser, in comparison to control plots $\left(0.5 \mathrm{mg} \mathrm{kg}^{-1}\right.$, relative amount 21). There were no statistically significant differences in the average $\mathrm{Cd}$ content in hybrid aspen tree rings between the control plots and fertilised plots. Nevertheless, the highest average $\mathrm{Cd}$ content was found in plots where wood ash fertiliser was applied $\left(1.2 \mathrm{mg} \mathrm{kg}^{-1}\right.$, relative amount 26); the lowest content was found in plots where the digestate fertiliser was applied ( $0.3 \mathrm{mg} \mathrm{kg}^{-1}$, relative amount 4.0).

The potential of Populus spp. for the phytoremediation of heavy metals is being confirmed under several experimental situations (Guerra et al. 2011). The recent study by Radojčić Redovniković et al. (2017) demonstrated that Populus spp. could be a good candidate for the phytoextraction processes of $\mathrm{Cd}$ in moderately-contaminated soils, while in heavily-contaminated soil it can only be considered as a phytostabiliser. For $\mathrm{Pb}$ remediation, only the phytostabilisation process can be considered. Furthermore, Mala et al. (2007) concluded that the hybrid aspen could accumulate large amounts of the toxic heavy metals $\mathrm{Cd}$ (800-1,500 mg kg-1) and $\mathrm{Pb}(5,000-13,000$ $\left.\mathrm{mg} \mathrm{kg}^{-1}\right)$ in the roots and about $100 \mathrm{mg} \mathrm{kg}^{-1}$ of $\mathrm{Cd}$ was also found in the above-ground part of the hybrid aspen. Furthermore, Mandre (2014) highlighted that high levels of heavy metals in the soil did not mean similar concentrations and ratios in plants growing in contaminated soil.

Results of our study demonstrated the significant impact of the fertiliser initially used (especially wood ash) on the average heavy metal content in hybrid aspen tree rings, despite the fact that the representative soil chemical analyses did not show a significant impact of the fertiliser initially used on heavy metal content in the soil. This can be explained by the well-known fact that a tree root system uptakes both nutrients and heavy metals from the soil; thereby the tree ring chemical content represents a much larger volume of soil, and thus more general growing conditions than the analyses of separate soil samples, especially considering that the mechanical spreading of fertiliser is not homogeneous. The results of analyses made using the ICP-MS method indicated that the $\mathrm{Hg}$ content in tree rings is below the detection limit $\left(0.06 \mathrm{mg} \mathrm{kg}^{-1}\right)$. The variation of $\mathrm{Hg}$ occurrence expressed in relative units (results of analyses made using LA-ICP-MS method) in hybrid aspen tree rings is presented in Fig. 3. The variation of the $\mathrm{Hg}$ relative amount in hybrid aspen tree rings was up to 2.0, but a large number of $\mathrm{Hg}$ measurements were below the detection limit as well. The tree ring average $\mathrm{Hg}$ relative amount ranged up to 0.32 (plot initially fertilised with digestate, sample tree $A_{3}$, tree ring formed in 2012). Comparing the average $\mathrm{Hg}$ relative amount in hybrid aspen tree rings in plots where different fertilisers were initially used, the highest average $\mathrm{Hg}$ relative amount in tree rings was 
found in plots fertilised with digestate (relative amount 0.11), while the lowest in plots fertilised with wood ash (relative amount 0.03). Additionally, statistically significant differences $(p<0.05)$ in the average $\mathrm{Hg}$ relative amount in tree rings were found between the control plots and plots fertilised with digestate.

Assad et al. (2016) recently demonstrated the role of the Populus spp. above-ground biomass in capturing the atmospheric $\mathrm{Hg}$ released from the soil. Molina et al. (2006) and Laacouri et al. (2013) hypothesised that variations in $\mathrm{Hg}$ uptake by the vegetation cover depended on a large number of factors including tree species, $\mathrm{Hg}$ concentrations in the soil and atmosphere, organisms, and season. Results of our study demonstrated statistically significant differences in average $\mathrm{Hg}$ relative amount in hybrid aspen tree rings between the control plots and the plots fertilised with digestate, although there were no statistically significant differences in total $\mathrm{Hg}$ content in the soil after the application of fertiliser according to soil chemical analyses. These results confirm the effectiveness of using hybrid aspen as a bioindicator.

\section{Relationship between heavy metal and} major element content

The characterisation of heavy metal transporters in Populus spp. is very scarce (Guerra et al. 2011). Calcium ions contained in the woody plant cell walls are known to be a part of pectin substances and bind non-methylated carboxyl groups of uronic acid. It is also well-known that pectin substances are highly effective regarding metal ion sorption and are widely used, for example, in medicine to remove toxic ions from human organisms (Silkin \& Ekimova 2012). Therefore, it would be logical to assume that calcium and heavy metal ions are part of the same polymer and, most probably, a part of the pectin substances.

The strength of the relationship between the analysed heavy metals $(\mathrm{Cd}, \mathrm{Hg}, \mathrm{Pb})$ and the content of the major elements $(\mathrm{Mg}, \mathrm{K}$, $\mathrm{Ca}$ ) in hybrid aspen tree rings is summarised in Tab. 5. The results of our study showed the strongest positive correlation $(r>0.5)$ between the annual tree ring average $\mathrm{Ca}$ and $\mathrm{Cd}$ content, and between the $\mathrm{Ca}$ and $\mathrm{Pb}$ content in hybrid aspen tree rings. Furthermore, in several hybrid aspen sample trees, a strong positive correlation was found between the annual tree ring average $\mathrm{Cd}$ and $\mathrm{K}$ content, and between the Cd and Mg content. Conversely, weak or no correlation was found between the tree ring average $\mathrm{Ca}$ and $\mathrm{Hg}$ content.

Analysing different fertilisation subplots separately, the strongest positive correlation between the annual tree ring average content of heavy metals and the major elements was found between the $\mathrm{Cd}$ and $\mathrm{Ca}$ content, and between the $\mathrm{Cd}$ and $\mathrm{Mg}$ content in all hybrid aspen sample trees in plots where wood ash fertiliser had been initially applied (on average, $r=0.87$ and $r=$

Tab. 5 - Variation of correlation coefficients $(r)$ between annual tree ring macroelement and heavy metal content $(\mathrm{Pb}$ and $\mathrm{Cd})$ or relative amount $(\mathrm{Hg})$ at an individual tree level. The frequency of occurrence of relevant correlation depending on the strength of correlation is shown.

\begin{tabular}{|c|c|c|c|c|}
\hline Element & $r$ value & $\mathrm{Pb}(\%)$ & Cd (\%) & $\mathrm{Hg}(\%)$ \\
\hline \multirow[t]{3}{*}{$\mathrm{Ca}$} & $r<-0.5$ & 17 & 17 & 33 \\
\hline & $-0.5<r<0.5$ & 33 & 8 & 42 \\
\hline & $r>0.5$ & 50 & 75 & 25 \\
\hline \multirow[t]{3}{*}{ K } & $r<-0.5$ & 33 & 25 & 25 \\
\hline & $-0.5<r<0.5$ & 33 & 25 & 67 \\
\hline & $r>0.5$ & 33 & 50 & 8 \\
\hline \multirow[t]{3}{*}{$M g$} & $r<-0.5$ & 8 & 0 & 25 \\
\hline & $-0.5<r<0.5$ & 58 & 25 & 33 \\
\hline & $r>0.5$ & 33 & 75 & 42 \\
\hline
\end{tabular}

0.83, respectively - Fig. 4). Unequivocally, a strong positive correlation was found between the annual tree ring average content of $\mathrm{Pb}$ and $\mathrm{Ca}$ in all hybrid aspen sample trees in the control plots (average $r$ was 0.77$)$.

Correlations between content of heavy metals and major elements in tree rings determined in this study can be explained by specific transport mechanisms of different clusters of elements in hybrid aspen. For example, P-type adenosine triphosphates (ATPases) are used to translocate a diverse set of ions, including $\mathrm{H}^{+}, \mathrm{Na}^{+} / \mathrm{K}^{+}, \mathrm{H}^{+} / \mathrm{K}^{+}$, and $\mathrm{Ca}^{2+}$, plus heavy metals and possibly lipids (Kuhlbrandt 2004). The $\mathrm{P}_{1 \mathrm{~B}}$-type ATPases, known as heavy metal ATPases (HMAs), are involved in the transport of a range of essential as well as potentially toxic metals across cell membranes.

Functional studies on the HMAs have shown these transporters to be divided into two subgroups based on their metalsubstrate specificity: a $\mathrm{Cu} / \mathrm{Ag}$ group and a
$\mathrm{Zn} / \mathrm{Co} / \mathrm{Cd} / \mathrm{Pb}$ group (Tangahu et al. 2011). Consequently, similar correlations between content of $\mathrm{Cd}$ and major elements in tree rings, as well as between content of $\mathrm{Pb}$ and major elements found in this study, are explained by the fact that both $\mathrm{Cd}$ and $\mathrm{Pb}$ belong to the same subgroup of metal-substrate specificity of HMAs, thereby transport and accumulation processes for $\mathrm{Cd}$ and $\mathrm{Pb}$ in stem tissues of hybrid aspen are similar.

Taking into account the growing interest in the use of hybrid aspen in SRWC systems, both in marginal lands and agricultural land, to mitigate the negative impacts on the environment caused by more intensive management (e.g., use of fertilisers), for phytoremediation purposes etc., further work is needed to fill the knowledge gaps pertaining to biochemical processes of element transport and accumulation in hybrid aspen tree rings and to determine the impact of environmental factors including climate change and weather extremes

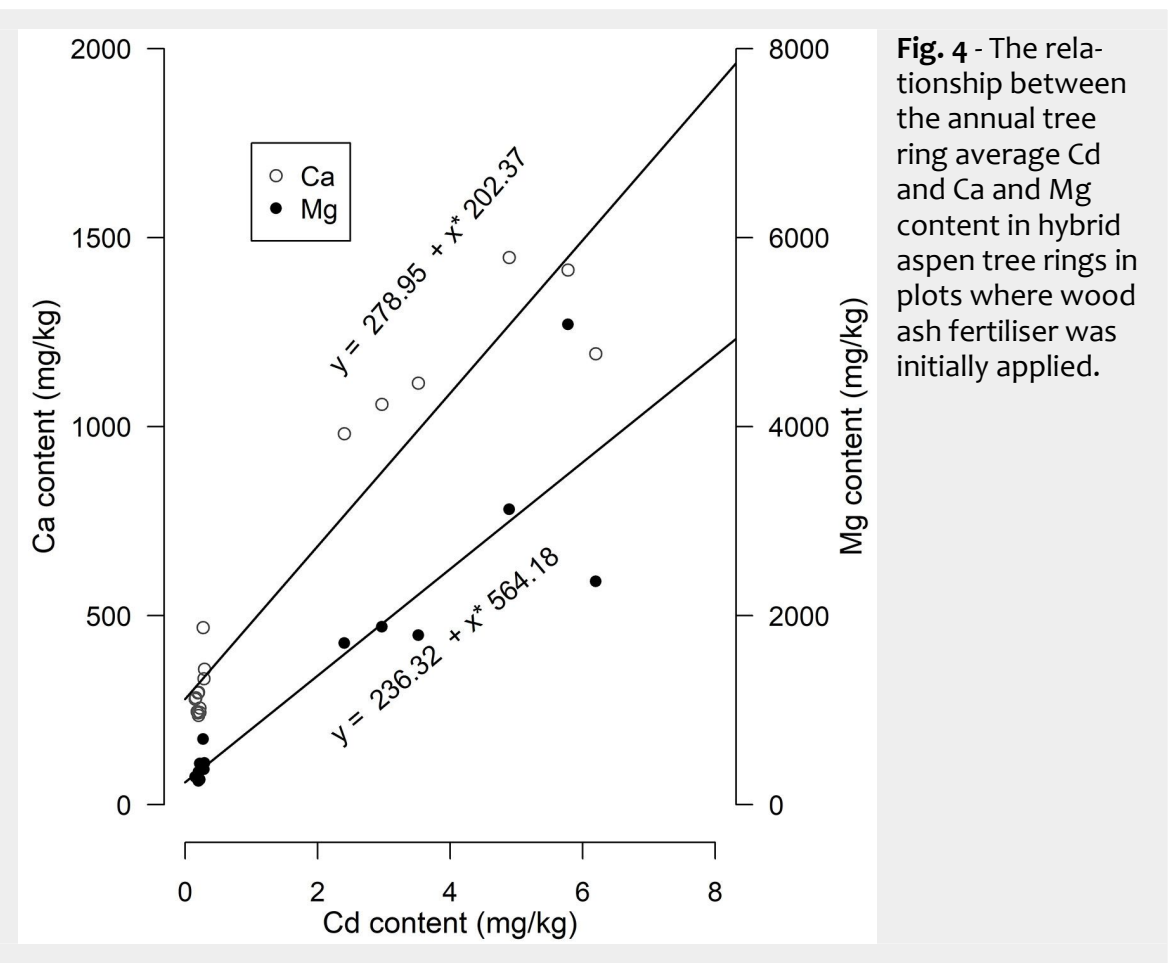


affecting the uptake of elements. Additional information is needed on the impact of different clones (genotypes) on the variation of major elements and heavy metal occurrence in hybrid aspen tree rings and on the synergetic effect between Populus spp. genotype and various levels and types of pollution in different climatic regions.

\section{Conclusions}

The results from the analysis of the content of major biologically important elements and heavy metals in the tree rings of six-year-old hybrid aspen (Populus tremuloides Michx. $\times$ P. tremula L.) cultivated in marginal agricultural land in hemi-boreal conditions and initially fertilised with digestate, sewage sludge, and wood ash can be summarised as follows.

Although content of major elements in the hybrid aspen stem plane varied considerably, the content of major elements in latewood were generally higher when compared to earlywood, showing a pronounced ring structure. This trend was not observed for heavy metals.

Initially-used fertilisers (especially wood ash) significantly impact content of major elements and heavy metals in hybrid aspen tree rings. Therefore, hybrid aspens can be considered as an effective bioindicator even if soil $\mathrm{pH}$ is near neutral, indicating a limited mobility of the heavy metals.

LA-ICP-MS in combination with ICP-MS was successful in describing spatial differences in the major element and heavy metal content in tree rings of hybrid aspen grown in different fertilisation regimes. Use of ICP-MS to quantify LA-ICP-MS data provided detailed spatial quantitative information on element content in tree rings that have the potential to fulfill knowledge gaps in dendrochemistry.

\section{Author Contributions}

D. Lazdina and A. Viksna conceived and designed the experiments; T. Vaculovic prepared and optimized the LA-ICP-MS experiments; A. Bardule, L. Busa, M. Tvrdonova and M.Bertins performed the experiments and data treatment; V. Kanicky and A. Viksna evaluated data and performed consultations; A. Bardule wrote the paper.

\section{Acknowledgments}

Establishment of the experimental plot was supported by the European Regional Development Fund's project "Elaboration of models for establishment and management of multifunctional plantations of short rotation energy crops and deciduous trees" (No. 2010/0268/2DP/2.1.1.2.0/10/API $\mathrm{A} / \mathrm{VIAA} / 118)$ and the continuation of the research work was supported by the European Regional Development Fund's project "Developing methods of plantation cultivation of fast-growing forest crops and evaluating the suitability of their wood for pelletizing" (No. 2013/0049/2DP/2.1.1.10/13/API A/VIAA/031). Results of the heavy metal isotope content in hybrid aspen tree rings were obtained during the short term scientific mission "Impact of fertilization on trace element content in Hybrid aspen coppice tree rings" under the COST Action FP1301. T. Vaculovic, M. Tvrdonova, and V. Kanicky give thanks for the financial support of the project CEITEC 2020 (LQ1601) of the Ministry of Education, Youth and Sports of the Czech Republic; and M. Tvrdonova thanks the Student Project Grant at MU (specific research, rector's program - MUNI/A 0886/2016). Preparation and publishing of paper was supported by European Union's Horizon 2020 research and innovation programme's project "Marginal Lands for Growing Industrial Crops: Turning a burden into an opportunity" (grant agreement No. 727698).

\section{References}

Assad M, Parelle J, Cazaux D, Gimbert F, Chalot M, Tatin-Froux F (2016). Mercury uptake into poplar leaves. Chemosphere 146: 1-7. - doi: 10.10 16/j.chemosphere.2015.11.103

Berger TW, Köllensperger G, Wimmer R (2004). Plant-soil feedback in spruce (Picea abies) and mixed spruce-beech (Fagus sylvatica) stands as indicated by dendrochemistry. Plant and Soil 264: 69-83. - doi: 10.1023/B:PLSO.0000047714.4 3253.25

Blanco-Canqui H (2016). Growing dedicated energy crops on marginal lands and ecosystem services. Soil Science Society of America Journal 80: 845-858. - doi: 10.2136/sssaj2016.03.00 80

Burken JG, Vroblesky DA, Balouet JC (2011). Phytoforensics, dendrochemistry, and phytoscreening: new green tools for delineating contaminants from past and present. Environmental Science and Technology 45: 6218-6226. - doi: 10.1021/es2005286

Calva-Vazquez G, Razo-Angel G, Rodriguez-Fernandez L, Ruvalcaba-Sil JL (2006). Study of Z > 18 elements concentration in tree rings from surroundings forests of the Mexico Valley using external beam PIXE. Nuclear Instruments and Methods in Physics Research Section B: Beam Interactions with Materials and Atoms 249 (12): 588-591. - doi: 10.1016/j.nimb.2006.03.061

Cocozza C, Ravera S, Cherubini P, Lombardi F, Marchetti $M$, Tognetti R (2016). Integrated biomonitoring of airborne pollutants over space and time using tree rings, bark, leaves and epiphytic lichens. Urban Forestry and Urban Greening 17: 177-191. - doi: 10.1016/j.ufug.2016.0 4.008

Confalonieri R, Jones B, Van Diepen K, Van Orshoven J (2014). Scientific contribution on combining biophysical criteria underpinning the delineation of agricultural areas affected by specific constraints. European Commission, Joint Research Centre, Institute for Environment and Sustainability, Publication Office of the European Union, Luxembourg, pp. 85.

Cui M, He X, Davi N, Chen Z, Zhang X, Peng J, Chen W (2012). Evidence of century-scale environmental changes: trace element in tree-ring from Fuling Mausoleum Shenyang, China. Dendrochronologia 31: 1-8. - doi: 10.1016/j.dendro.20 11.09.003

DeWalle DR, Tepp JS, Swistock BR, Edwards PJ,
Sharpe WE, Adams MB, Kochenderfer JN (2002). Dendrochemical response to soil fertilization. In: Proceedings of the " $13^{\text {th }}$ Central Hardwood Forest Conference" (Van Sambeek JW, Dawson JO, Ponder Jr F, Loewenstein EF, Fralish JS eds). University of Illinois, UrbanaChampaign (IL, USA) 1-3 Apr 2002. USDA Forest Service, North Central Research Station, St. Paul, MN, USA, pp. 480-488.

Fromm J (2010). Wood formation of trees in relation to potassium and calcium nutrition. Tree Physiology 30 (9): 1140-1147. - doi: 10.1093/tree phys/tpq024

Ghezehei SB, Shifflett SD, Hazel DW, Nichols EG (2015). SRWC bioenergy productivity and economic feasibility on marginal lands. Journal of Environmental Management 160: 57-66. - doi: 10.1016/j.jenvman.2015.05.025

Glass GA, Hasenstein KH, Hsi-Tsung C (1993). Determination of trace element concentration variations in tree rings using PIXE. Nuclear Instruments and Methods in Physics Research Section B: Beam Interactions with Materials and Atoms 79: 393-396. - doi: 10.1016/0168-583X (93) $95370-\mathrm{K}$

Guerra FP, Gainza-Cortes FI, Perez-Castro R, Zamudio $F$ (2011). Phytoremediation of heavy metals using poplars (Populus Spp.): a glimpse of the plant responses to copper, cadmium and zinc stress. In: "Handbook of Phytoremediation" (Golubev IA ed). Nova Science Publishers, USA, pp. 387-414. [online] URL: http://www. researchgate.net/publication/230059005

Hoffmann E, Ludke C, Scholze H, Stephanowitz $H$ (1994). Analytical investigations of tree rings by laser ablation ICP-MS. Fresenius Journal of Analytical Chemistry 350: 253-259. - doi: 10.1007/ BFoo322478

Komárek M, Ettler V, Chrastny V, Mihaljevič M (2008). Lead isotopes in environmental sciences: a review. Environment International 34: 562-577. - doi: 10.1016/j.envint.2007.10.005 Kuczumow A (2004). Microprobe investigations of patterned natural and petrified biological objects. Journal of Alloys and Compounds 362: 71-82. - doi: 10.1016/S0925-8388(03)00565-6 Kuhlbrandt W (2004). Biology, structure and mechanism of P-type ATPases. Nature Reviews Molecular Cell Biology 5 (4): 282-95. - doi: 10.103 8/nrm1354

Laacouri A, Nater EA, Kolka RK (2013). Distribution and uptake dynamics of mercury in leaves of common deciduous tree species in Minnesota, USA. Environmental Science and Technology 47: 10462-10470. - doi: 10.1021/es401357z Levy G, Brechet C, Becker M (1996). Element analysis of tree rings in pedunculate oak heartwood: an indicator of historical trends in the soil chemistry, related to atmospheric deposition. Annals of Forest Science 53: 685-696. doi: 10.1051/forest:19960246

MacDonald HC, Laroque CP, Fleming DEB, Gherase MR (2011). Dendroanalysis of metal pollution from the Sydney Steel Plant in Sydney, Nova Scotia. Dendrochronologia 29: 9-15. - doi: 10.1016/j.dendro.2010.08.001

Maillard F, Girardclos O, Assad M, Zappelini C, Pérez Mena JM, Yung L, Guyeux C, Chrétien S, Bigham G, Cosio C, Chalot M (2016). Dendrochemical assessment of mercury releases from a pond and dredged-sediment landfill impacted 
by a chlor-alkali plant. Environmental Research 148: 122-126. - doi: 10.1016/j.envres.2016.03.034 Mala J, Machova P, Cvrčkova H, Vanek T (2007). Heavy metals uptake by the hybrid aspen and rowan-tree clones. Journal of Forest Science 53: 491-497. - doi: 10.17221/2022-JFS

Mandre M (2014). Heavy metals uptake and accumulation by the hybrid aspen in alkalised soil. Water, Air, and Soil Pollution 225 (1): 356. - doi: 10.1007/s11270-013-1808-6

Molina JA, Oyarzun R, Esbrí JM, Higueras P (2006). Mercury accumulation in soils and plants in the Almadén mining district, Spain: one of the most contaminated sites on Earth. Environmental Geochemistry and Health 28: 487-498. - doi: 10.1007/s10653-006-9058-9

Nabais C, Freitas H, Hagemeyer J (1999). Dendroanalysis: a tool for biomonitoring environmental pollution? Science of the Total Environment 232: 33-37. - doi: 10.1016/So048-9697(99) 00107-2

Perone A, Cocozza C, Cherubini P, Bachmann O, Guillong M, Lasserre B, Marchetti M, Tognetti R (2018). Oak tree-rings record spatial-temporal pollution trends from different sources in Terni (Central Italy). Environmental Pollution 233: 278-289. - doi: 10.1016/j.envpol.2017.10.062

Prohaska T, Stadlbauer C, Wimmer R, Stingeder G, Latkoczy C, Hoffmann E, Stephanowitz H (1998). Investigation of element variability in tree rings of young Norway spruce by laser-ablation-ICPMS. Science of the Total Environment 219: 29-39. - doi: 10.1016/So048-9697(98)00224-

R Core Team (2017). R: a language and environment for statistical computing. The R Foundation for Statistical Computing, Vienna, Austria. [online] URL: http://www.r-project.org

Radojčić Redovniković I, De Marco A, Proietti C, Hanousek K, Sedak M, Bilandić N, Jakovljević T (2017). Poplar response to cadmium and lead soil contamination. Ecotoxicology and Environmental Safety 144: 482-489. - doi: 10.1016/j.eco env.2017.06.011

Rockwood DL, Naidu CV, Carter DR, Rahmani M, Spriggs TA, Lin C, Alker GR, Isebrands JG, Segrest SA (2004). Short-rotation woody crops and phytoremediation: opportunities for agroforestry? Agroforestry Systems 61: 51-63. - doi: 10.1007/978-94-017-2424-1_4

Saarela T (2009). Elemental analysis of wood materials by external millibeam thick target PIXE. Process Chemistry Centre Laboratory of
Analytical Chemistry Faculty of Mathematics and Natural Sciences and Accelerator Laboratory Abo Akademi University, Abo, Finland, pp. 74. [online] URL: http://www.doria.fi/handle/ $10024 / 59480$

Scharnweber T, Hevia A, Buras A, Van Der Maaten $E$, Wilmking $M$ (2016). Common trends in elements? Within- and between-tree variations of wood-chemistry measured by X-ray fluorescence - A dendrochemical study. Science of the Total Environment 566-567: 1245-1253. - doi: 10.1016/j.scitotenv.2016.05.182

Schnoor JL (1997). Phytoremediation, technology evaluation report. The University of lowa, lowa, USA, pp. 43.

Sensula B, Wilczynski SR, Monin L, Allan M, Pazdur A, Fagel N (2017). Variations of tree ring width and chemical composition of wood of pine growing in the area nearby chemical factories. Geochronometria 44: 226-239. - doi: 10.1515 /geochr-2015-0064

Sherene T (2010). Mobility and transport of heavy metals in polluted soil environment. Biological Forum - An International Journal 2 (2): 112-121.

Silkin P, Ekimova NV (2012). Relationship of strontium and calcium concentrations with the parameters of cell structure in Siberian spruce and fir tree-rings. Dendrochronologia 30: 189194. - doi: 10.1016/j.dendro.2011.06.003

Smith KT, Shortle WC (1996). Tree biology and dendrochemistry. In: "Radiocarbon" (Dean JS, Meko DM, Swetnam TW eds). University of Arizona, Tucson, USA, pp. 629-635. [online] URL: http://www.fs.usda.gov/treesearch/pubs/15513 Smith KT, Balouet JC, Shortle WC, Chalot M, Beaujard F, Grudd H, Vroblesky DA, Burken JG (2014). Dendrochemical patterns of calcium, zinc, and potassium related to internal factors detected by energy dispersive X-ray fluorescence (EDXRF). Chemosphere 95: 58-62. - doi: 10.1016/j.chemosphere.2013.08.017

Taiz L, Zeiger E (2010). Plant physiology. Sinauer Associates Inc., Sunderland, MS, USA, pp. 782.

Tangahu BV, Sheikh Abdullah SR, Basri H, Idris M, Anuar N, Mukhlisin M (2011). A review on heavy metals ( $\mathrm{As}, \mathrm{Pb}$, and $\mathrm{Hg}$ ) uptake by plants through phytoremediation. International Journal of Chemical Engineering 2011 (4): 1-31. - doi: 10.1155/2011/939161

Vaganov EA, Grachev AM, Shishov VV, Panyushkina IP, Leavitt SW, Knorre AA, Chebykin EP, Menyailo OV (2013). Elemental composition of tree rings: a new perspective in biogeochemistry. Doklady Biological Sciences 453: 702-706. - doi: 10.1134/So012496613060203

Valujeva K, Grinfelde I, Straupe I (2016). Phytoremediation. Usage opportunities in Latvia. Latvijas Lauksaimniecibas Universitate, Jelgava, Latvia, pp. 112. [in Latvian]

Van Den Bulcke J, Wernersson ELG, Dierick M, Van Loo D, Masschaele B, Brabant L, Boone MN, Van Hoorebeke L, Haneca K, Brun A, Luengo Hendriks CL, Van Acker J (2014). 3D tree-ring analysis using helical X-ray tomography. Dendrochronologia 32: 39-46. - doi: 10.1016/j.den dro.2013.07.001

Vašinová-Galiová $M$, Nyvltová-Fišáková $M$, Kynicky J, Prokeš L, Neff H, Mason AZ, Gadas P, Košler J, Kanicky V (2013). Elemental mapping in fossil tooth root section of Ursus arctos by laser ablation inductively coupled plasma mass spectrometry (LA-ICP-MS). Talanta 105: 235243. - doi: 10.1016/j.talanta.2012.12.037

Viger M, Smith HK, Cohen D, Dewoody J, Trewin H, Steenackers M, Bastien C, Taylor G (2016). Adaptive mechanisms and genomic plasticity for drought tolerance identified in European black poplar (Populus nigra L.). Tree Physiology 36 (7): 909-928. - doi: 10.1093/treephys/tpw017 Watmough SA (1997). An evaluation of the use of dendrochemical analyses in environmental monitoring. Environmental Review 5: 181-201. doi: 10.1139/a97-010

Watmough SA, Hutchinson TC, Evans RD (1998). The quantitative analysis of sugar maple tree rings by laser ablation in conjuction with ICPMS. Journal of Environmental Quality 27: 10871094. - doi: 10.2134/jeq1998.0047242500270005 0014X

Watt SFL, Pyle DM, Mather TA, Day JA, Aiuppa A (2007). The use of tree-rings and foliage as an archive of volcanogenic cation deposition. Environmental Pollution 148: 48-61. - doi: 10.1016/j. envpol.2006.11.007

Yanosky TM, Carmichael JK (1993). Element concentrations in growth rings of trees near an abandoned wood-preserving plant site at Jackson, Tennessee. Water-Resources Investigations Report 93-4223, Reston, VI, USA, pp. 1-72. [online] URL: http://pubs.usgs.gov/wri/1993/42 23/report.pdf

Zalesny JA (2007). Phytoremediation of land fill leachate using Populus. Retrospective theses and dissertations, lowa State University, Ames, Iowa, USA, pp. 228. 